\title{
A DECONSTRUCTION OF THE TERM "REVOLUTION"
}

Author:

Dr JCM Venter ${ }^{1}$

Prof EG Bain²

\section{Affiliation:}

'Senior Lecturer, Political Studies, Potchefstroom

Campus, North-West

University

${ }^{2}$ Senior Researcher, Bench Marks Centre for Corporate Social Responsibility, Potchefstroom Campus, North-West University

\section{Correspondence to:}

Dr JCM Venter

Email:

jan.venter@nwu.ac.za

\section{Postal address:}

4 Meul Street,

Potchefstroom, 2531.

\section{Correspondence to:}

Prof EG Bain

Email:

eddie.bain@nwu.ac.za

\section{Postal address:}

Internal Box 312, Private Bag X6001, Potchefstroom Campus, North-West University, Potchefstroom, 2520.

\section{Dates:}

15 Dec 2015

How to cite this article: Venter, J.C.M. \& Bain, E.G., 2015. "A deconstruction of the term "revolution"". KOERS - Bulletin for Christian Scholarship, 80(4). Available at: http:// dx.doi.org/10.19108/ koers.80.4.2246

\section{Copyright:}

(c) 2015. The Author(s).

Published under the

Creative Commons

Atribution License.
The precise meaning of the concept of (political) revolution remains semantically contested. According to Arslanian (2013:127) this concept "is often used liberally, applied to everything from the 'Social Media Revolution' to the 'Sexual Revolution'". Brinton (1965:1-4) agrees, referring to revolution as a concept that "troubles the semanticist not only because of its wide range in popular usage, but also because it is one of those words charged with emotional content". In some instances revolution even becomes a "holy word" with an a priori moral force which sets preconditions for moral righteousness. It seems that "the revolution" can become just as important as a religion would be. This same revolution/religion also provides the opportunity to gain material and immaterial goods for human-kind (Marcuse, 2001:123). Koselleck (as quoted by Marinelli; 2014:8) argues that the semantics of the concept revolution is by no means unequivocal. The goal of this article therefore is to address the semantic vagueness of the political concept of revolution through a literature analysis, subsequently listing observable characteristics of the phenomenon. As such, this article is a theoretical effort contributing to what Babbie and Mouton (2008:113) call the hermeneutic cycle of ever-deepening understanding in which the different observables of revolution will be arrived at via the deconstruction of various definitions from wide-ranging schools of thought and ideas of revolution.

Key concepts: Revolution, deconstruction; characterisation.

Die presiese betekenis van die konsep (politieke) revolusie is semanties omstrede. Volgens Arslanian (2013:127) word die konsep algemeen gebruik om enigiets van die 'Sosiale Media Revolusie' tot die 'Seksuele Revolusie' te beskryf. Brinton (1965:1-4) stem hiermee saam en beskryf revolusie as 'n konsep wat problematies is vir die semantikus omdat dit in die populêre taal gebruik word en omdat dit met emosionele inhoud gelaai is. In sommige omstandighede word revolusie selfs' $n$ "heilige woord" met' $n$ a priori morele mag wat die voorvereistes bevat vir geregtigheid. Dit blyk dat "die revolusie" net so belangrik kan raak soos wat'n religie kan wees. Hierdie revolusie/religie voorsien dan die geleentheid om materiële en niemateriële goedere deur die mensdom te versamel (Marcuse, 2001:123). Koselleck (soos aangehaal deur Marinelli 2014:8) argumenteer dat die betekenis van revolusie allermins ondubbelsinnig is. Die doel van die artikel is dan om die semantiese vaagheid van die politieke term rewolusie te ontleed deur 'n literatuurstudie waarna die waarneembare kenmerke van die verskynsel gelys sal word. As sulks poog die artikel om 'n teoretiese bydrae te maak tot wat Babbie and Mouton (2008:113) die hermeneutiese siklus van dieperwordende begrip noem en waarin verskillende waarneembare kenmerke van revolusie geïdentifiseer sal word deur die dekonstruksie van verkillende definisies beskryf in verskillende denkskole.

Kernbegrippe: Revolusie, dekonstruksie; karakterisering. 


\section{A deconstruction of the term "revolution"}

\section{INTRODUCTION}

The precise meaning of the concept of (political) revolution remains discursive. According to Arslanian (2013:127) this concept "is often used liberally, applied to everything from the 'Social Media Revolution' to the 'Sexual Revolution'". Brinton (1965:1-4) agrees with this statement, calling revolution a "looser word" that "troubles the semanticist not only because of its wide range in popular usage, but also because it is one of those words charged with emotional content". Koselleck (as quoted by Marinelli, 2014:8) argues in a similar vein and states that the semantics of the concept revolution is by no means unequivocal, due to the fact that it has become a modern slogan. Marinelli (2014:10) further argues for a semantic analysis to restore meaning to a word often used in society and politics, also in South Africa. In China and South Africa for example the concept revolution is almost a "holy word" with an a priori moral force which sets preconditions "for the moral righteousness of each and every other thing" (Xiaobo, as quoted by Marinelli 2014:10). It seems that "the revolution" can become just as important as a religion would be. This same revolution/religion also provides the opportunity to gain material and immaterial goods (Marcuse, 2001:123).

Given what was said above, this article will address the semantic vagueness of the political concept of revolution through a literature analysis, subsequently listing observable characteristics of the phenomenon of political revolution gained from the literature. The process of literature analysis entails a deconstruction of various sources that according to Hirst (2014:15) mobilizes analytical and conceptual tools in a critical way and resist traditions, thoughts and praxis from which the tools and even the author originate.

The literature that will be used in this article can be divided into the following sections:

Firstly, the various definitions from the various traditions and schools of thought dealing with the definition of the concept of revolution will be deconstructed to find descriptive elements. Secondly, the works of three eminent scholars (each from a different school of thought regarding revolution) will be deconstructed in order to add to the list of characteristics. Firstly, however, a note on methodological aspects employed in this article.

For the purposes of this article deconstruction is defined as the examination that challenges comfortable assumptions about the topic under analysis (Hirst, 2014:15; Rossetti, 1992:211). Furthermore the structure of the article will be deductive in analysing existing literature and schools of thought and collating specific observables for the concept revolution. Thus this article will endeavour to arrange and systematise the specific observables of the concept 'revolution' found in the different branches of the various schools of thought. As such, this article is a theoretical effort contributing to what Babbie and Mouton (2008:113) call the hermeneutic cycle of everdeepening understanding in which the different observables of revolution will be arrived at via the deconstruction of various definitions from wide-ranging schools of thought and ideas.

This list of observables can be seen as a nominal definition, or what Babbie and Mouton (2008:113) call a proposed working definition or tentative definition. In a follow-up article these characteristics will then be proposed as a working definition and will be tested against a revolution that occurred during the "Arab Spring" of 2010 to 2015. Firstly, however, an analysis of the academic traditions concerning the study of the idea and concept of revolution.

\section{ACADEMIC TRADITIONS AND SCHOOLS OF THOUGHT}

Three main traditions exist that offer definitions of the concept 'revolution': firstly, the Marxists with scholars/practitioners such as Lenin, Mao and Marx; secondly, the Functionalists with scholars such as Huntington, Brinton and Pettee; and a third group (with sub-groups) offering Psychological explanations. It goes without saying that the various definitions generated by these various schools do not emphasise the same principles and that there is some degree of confusion as to what a revolution is. In the following paragraphs, examples will be provided of definitions of the concept of revolution from the various traditions and schools of thought identified above. These definitions will be deconstructed and the various elements of revolution will be identified in order to formulate observable elements of revolution.

\section{THE DECONSTRUCTION OF DEFINITIONS AND THE IDENTIFIABLE ELEMENTS OF REVOLUTION}

Firstly, an example of a Functionalist definition:

"A revolution is a rapid, fundamental, and violent domestic change in the dominant values and myths of society, in its political institutions, social structure, leadership and government activity and policies" (Huntington 2006:264).

To a functionalist, conflict (revolution) is seen as common, even endemic, but not necessary or desirable. In this sense, violence and revolution constitute only one of the many ways in which social change can develop. Thus, revolution is the exception, not the norm. The Mass Society theory (as a subgroup of the Functionalist theory) argues that the presence of certain structural characteristics in society provides inbuilt stability. If for some reason these traditional structures disengage, the probability of mass revolution increases. Huntington (2006:55), however, sees a revolution as a relatively temporary phenomenon with a beginning and an end that are usually not too far apart. 
Secondly, an example of a Marxist definition:

The history of all hitherto existing society is the history of class struggles. Freeman and slave, patrician and plebeian, lord and serf, guild-master and journeyman, in a word, oppressor and oppressed, stood in constant opposition to one another, carried on an uninterrupted, now hidden, now open fight, a fight that each time ended, either in a revolutionary reconstitution of society at large, or in the common ruin of the contending classes (Marx 1992:3).

For Marxist scholars, revolution is a necessary predestined locomotive of history; it is the law of nature, and so indeed all history is the story of revolution. Revolution, thus, will of necessity occur; although as becomes clear from the works of Lenin and Mao, a revolutionary must strategize, keep secrets and operate undercover to promote certain desirable outcomes. The revolutionary process is not necessarily an open process; it must be a strategized one, reliant on move and countermove. Thus, the process of revolution is not necessarily a process that will be completed rapidly. Mao speaks of "a hundred years" for the Chinese Revolution and Trotsky of a "permanent revolution" with all Marxists aiming to align into a World Revolution: “...it is impossible for a genuine people's revolution to win victory in any country without various forms of help from the international revolutionary forces..." (Zedong as quoted by Turok 2012:61).

Thirdly, an example of a Psychological explanation:

A revolution will occur when a population concludes that its situation is so undesirable that it can stand it no more. In order to alleviate its situation it rises up and destroys its oppressors. Or, a population have some idea of what they ought to be receiving during the general course of their lives. When they find themselves confronted with a situation in which the gap between what they think they ought to be getting and what they are getting is growing, and is getting wider and wider, they are likely to rise up. The work of Davies (1962:6) and his J-curve serves as an example of this last group (Cohan 1975:3).

According to the J-curve, people's expectations rise over time due to modernisation. If reality does not keep track of expectations, the gap between the two becomes larger and larger and the revolutionary potential increases, as illustrated in Figure 1. This, according to Cohan (1975:193), is one of the theories of rising expectations.
Figure 1: Davies' J-curve

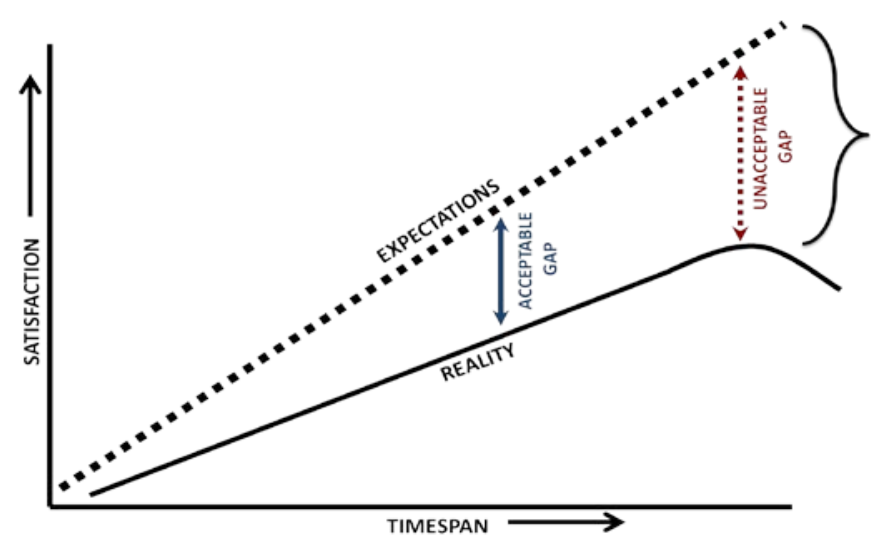

Source: Davies, 1962:6

Combining these definitions, explanations and their broader associated academic frameworks, Cohan (1975) postulates that a definition of revolution should encompass the following observable elements:

- an alteration of values or the myth of a particular system;

- $\quad$ an alteration of the social structure;

- a change in the political institutions;

- legality or illegality of the change;

- $\quad$ elite alteration, and

- the use of violence.

These elements need to be further clarified. The alteration of values or dominant myths, according to Huntington (2006:264), is a universally accepted element of revolution. Structural alteration too is a fundamental characteristic of a revolution as it is a transition from one historical epoch to another. Hence, a revolution is a transformation of an entire system. Institutional change may be the abolishment of an institution or the abolishment of some of the functions of an institution; it may also create new institutions or new functions for an institution. Pettee (1938:22) suggests a reconstitution of the state, to such an extent that, in accordance with Huntington, not only are the institutions redesigned but also the myths and values that underpin them. Elite alteration may be as simple as a personnel change, or as complicated as an elite transfusion by drawing a new elite from a different class and eradicating the old elite or class. Legality or illegality has to do with the fact that at some point the revolution is designated illegal by the regime, and upon success, the previous 'terrorist rebels' become the new legal government if they have legitimacy in the eyes of the citizens and the international community. Violence is a key ingredient in the Huntington definition; it is also a key concept in the Marxian notion of revolution. Mao Zedong famously noted that revolution is not a tea party; thus, it is safe to assume that a revolution will entail some sort of violence, if not outright terror and terrorism (Cohan 1975:14-27; Marek 1969:121). 
However, these elements only form part of the available knowledge on revolution. A perspective that has to be added to the six elements already discussed is that a revolution is a process (Mao, Trotsky and Marx); revolution is seldom a single event. The process involves many techniques, ranging from general strikes to coup d'états, to revolutionary wars, to even peaceful events such as 'democratic breakthroughs', the so-called Bourgeois Revolution/democracies of Trotsky, and negotiations, yet the revolution continues until its final goals are met (Greene 1990:14). "There is no reason to consider guerrilla warfare separately from national policy" (Zedong 2009a:5). "When the enemy advances we retreat. If the enemy's forces were weaker than ours, he would not dare advance... When the enemy retreats we pursue" (Zedong 2009b:11). From the above-mentioned it is possible to deduce two other elements that should be added:

- revolutions pragmatically ebb and flow, and

- $\quad$ revolutions seldom are single events; they are processes and need time to fulfil their goals.

Both Greene (1990) and Cohan (1975) state that the revolutions that have been studied in the past have been the so-called Great Revolutions. Four of these great revolutions are studied by Brinton (1965) in his book, The Anatomy of Revolution. There are also a myriad of incomplete revolutions or unsuccessful revolutions that, according to Greene (1990:14), if studied, could contribute not only to the study of revolution as a process, but also to the fact that revolution should be understood along the lines of a continuum of patterns of collective behaviour.

If it is understood that revolution is not conducted in isolation or by individuals, or even by small groups, a ninth element becomes discernible:

- Revolution is a pattern of collective behaviour (Greene) that needs the support of the masses (Mao).

Huntington (2006:1) states that the most important distinction between countries is their degree of government. It appears that Huntington and Greene are essentially in agreement with the view of complete order at one end of a continuum, and revolution somewhere toward the other end on the same continuum, which is illustrated below.

\section{Figure 2: Understanding the Revolutionary Continuum}

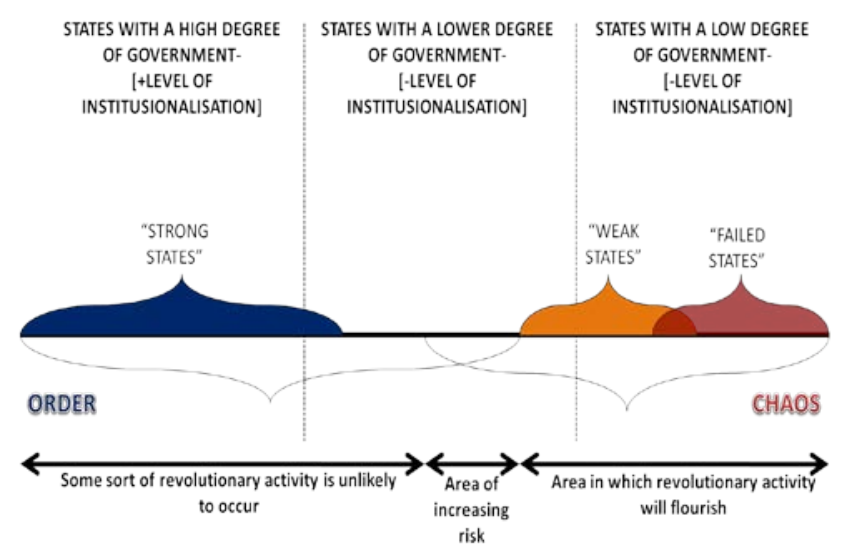

\section{Source: Own construct}

Importantly, revolution is not a single 'point', it is 'a scale' of intensity of conflict, and only one alternative with intensitylevels that may fluctuate, due to for instance, rebel strength, or strategy, and the degree of government in a state. Thus, a revolution is unlikely to occur in a state where there is a high degree of (good) government, such as in Switzerland, Germany or the United Kingdom, and more likely to occur where people are aware that they are deprived of services by a lower degree of government (see Davies' J-curve), or where they are trying to modernise (Huntington \& Brinton ${ }^{1}$ ).

This leads to a tenth element:

- Revolution has to be understood along a continuum.

As was said in the introduction, "the revolution" in some countries contains a moral imperative of righteousness. Everything done in the name of the revolution is in an almost religious sense correct or necessary. The claim is then made that when somebody speaks in the name of "the revolution" he or she speaks with the force of justice.

This leads to an eleventh element of revolution that can be described as follows:

- Revolution acquires a moral/religious force that justifies actions.

The above-mentioned elements provide observable characteristics found in the literature on revolution and form an analytical base (characterisation) for the concept of revolution. The observable elements of revolution thus far compiled are:

1. A revolution involves an alteration of values or the myth of a particular system;

2. an alteration of the social structure;

3. a change in the political institutions;

4. a change in what is legal and illegal (legality or illegality of 
the change);

5. an elite alteration;

6. the use of violence;

7. revolutions pragmatically ebb and flow;

8. revolutions seldom are single events; they are processes and need time to fulfil their goals.

9. revolution is a pattern of collective behaviour that needs the support of the masses;

10. revolution has to be understood along a continuum of intensity; and

11. revolution acquires a moral/religious force that can justify actions $^{2}$.

The characteristics of revolution were arrived at by the analysis of definitions available in the academic literature on the subject. In an effort to gain more theoretical reference, or to find grounds to discredit some elements above, the work of pre-eminent scholars from the Great Revolution schools, the Functionalists and the Neo-Marxists, are analysed in more detail. The first scholar set apart for further analysis is Crane Brinton from the Great Revolution School.

\section{CRANE BRINTON (THE STUDY OF GREAT REVOLUTIONS)}

In his book The Anatomy of Revolution (1975) Brinton analyses four revolutions, namely the English (1640-1660), the French (1789-1799), the American (1775-1783), and the Russian (1917) revolutions, all extensive or grand milestone revolutions (Brinton 1965:23-24). The goal of Brinton's comparison is "to see whether there are not in these four revolutions uniformities which can be grouped together..." (Brinton 1965:78). The results of his comparison produce insights, firstly concerning the old regimes, followed by the first stages of the revolution, the rule of the moderates, the accession of the extremists, the reigns of terror and virtue, and thermidor.

\subsection{The old regimes}

When studying the old regimes (the regimes against which the revolution is aimed), Brinton (1965:39) looks for signs of the impending breakdown. One of his findings was that all the revolutions were preceded by an inept ruling class: the Tsar of Russia ignorant of the majority of the peasants' plight; the aristocracy in France, the monarchy in Britain, ignorant of the

$2 \quad$ Examples of this can be found in the Arab spring in Egypt where the Muslim Brotherhood as a political and religious organisation superseded other secular organisations in the revolution in that country. The most interesting example of a revolution driven by religion is the one of ISIS or ISIL (Islamic State of Iraq and al-Sham or Islamic State of Iraq and the Levant). This revolutionary movement is unique in history as it is the first one to claim territory. power and plight of their new colony in America; and Charles I of England suspending parliament in an arrogant assumption of the divine right of kings. Implicit in this ineptitude, but not explicitly stated by Brinton, is the fact that a small privileged minority were not cognisant of, not only the wishes of the masses, but also their relative socio-economic deprivation or their perception thereof and their thinking on the issue; the masses were not going to tolerate it any longer, and in the minds of the ruling class the perception remained that this could be dealt with, usually by means of arms used with brutal force (Brinton 1965:53).

Another factor Brinton (1965:39) identifies is the transfer of the allegiance of the intellectuals. The masses' perception of their situation, or their actual situation, usually brings about a distancing between groups (the oppressor and oppressed in the Marxist vernacular). As soon as the intellectuals (usually a more privileged group) switch their allegiance, two things occur. The masses become more organised and their opinions are expressed more clearly, while the opposition loses the ability to generate new thinking (ideology) in what can be termed the first stages of the revolution.

\subsection{The first stages of the Revolution}

According to Brinton, it is difficult to determine exactly when a revolution began (or when it ended). For Brinton (1965:86), the most important uniformity he discerned in his comparison of the revolutions was that at one point or another in the first stage of revolution the constituted authority was challenged. "In such instances the routine response of any authority is to have recourse to force..." (Brinton 1965:86). According to Brinton, the results of this recourse were, according to his case studies, unsuccessful; therefore, the first stage ends with the victory of the revolutionists and the beginning of a short honeymoon period, the rule of the moderates.

\subsection{The rule of the moderates}

After the victory the business of government and governing by the victorious revolutionaries begins. At first the moderates ascend into positions of primacy. These people have been the primary opposition and it seems only natural that they form the new government. However, it is difficult to provide for all the needs of the people, and it is equally difficult not to seem similar to the previous elite, or even to assimilate the previous elite, some of their priorities and some of their goals. "At this stage in the revolution, the moderates in control of the formal machinery of government are confronted by the extremists, or if you prefer, merely by radical and determined opponents, in control of machinery devised for propaganda, pressure-group work, even insurrection" (Brinton 1965:122).

Faced by the opposition of the more radical groups (who might have been alliance partners against oppression) organised in the network of "the illegal government", the moderates have three choices: they may try to suppress the illegal government, they may try to gain control of it, or they may try to ignore it. In reality, according to Brinton (1965:137), policy usually varies between these alternatives, resulting in a situation that 
only serves to encourage the enemies of the current regime, resulting in the accession of the extremists.

\subsection{The accession of the extremists}

The accession of the extremists "is marked by a series of exciting episodes: here street fighting, there forced seizure of property, almost everywhere heated debates, attempted repressions, a steady stream of violent propaganda" (Brinton 1965:148).

The extremists gain control of government because they secure control over the network of the illegal government. They oust any and all active and effective opponents from all organisations within the illegal government; thus, the centralisation, authority, discipline and single-mindedness of the successful extremists are first developed within the realm of the network of the illegal government. These characteristics remain when the illegal government becomes legal and the reigns of terror and virtue begin (Brinton 1965:175-177).

\subsection{The reigns of terror and virtue}

According to Brinton (1965:177), the reign of terror is not limited only to the significant objects such as the guillotine, or the hangman's noose; it also occurs in everyday life. In fact, politics becomes everyday life during the reign of terror. Political indifference becomes impossible, and has different meanings for the insider and the outsider. For the outsider, defined as not actively hostile, the average person not directly involved and not on the bandwagon, life becomes complicated. He has to prove himself to be above suspicion and in line with the new thinking and vernacular. Missteps can lead to social alienation, loss of work, detention, and even death. For the insider, a person who is part of the new epoch, the new revolutionary calendar can be very exciting; everyone is confronted by the fact that...

If there is only one truth, and you have that truth completely, toleration of differences means an encouragement to error, crime, evil, sin. Indeed toleration in this sense is harmful to the tolerated, as well as very trying on the tolerator... it is a positive benefit to the obstinate heretics to kill them because the longer they live the more damnation they heap upon themselves (Brinton 1965:194).

Thus there is immense pressure on the individual to do what is commonly accepted. When the reigns of terror and virtue subside, what follows is thermidor.

\subsection{Thermidor}

Brinton (1965:205) calls thermidor a period of convalescence from the fever of the revolution. He is quick to add that this period is not benign and it is not easy to determine when the rule of the extremists subsides into thermidor. According to Brinton, this period is primarily characterised by the establishment of a tyrant or an unconstitutional leader. There is also a return to the church in one sense or another and an observable search for pleasure. "With the abandonment of price fixing and in the inflation that followed, a class of newly rich speculators, war profiteers and clever politicians arose"
(Brinton 1965:219). Along with sexual perversion, prostitutes, and the "gilded youth", all the revolutionaries at this stage seem intent on spending money, seemingly forgetting the past.

In summation: the following aspects regarding revolution are important according to Brinton:

Brinton's contribution by way of comparing the four revolutions has at its core the various stadia into which he places various aspects of the (completed, great) revolutions. Despite the noted contribution Briton makes, he does not include the "incomplete revolutions" that Huntington mentions, or the more detailed analysis of the causes of revolution that the Marxist scholars and the scholars offering psychological explanations pay so much attention to. Furthermore, in this very short overview of Brinton's The Anatomy of Revolution nothing is found that contradicts the eleven elements described in section 3 of this article. In fact, Brinton emphasises several of the definition's elements. The facts that revolutions evolve through stages, which will at times involve illegal actions that include violence, are elements already included. Brinton, however, adds subtleties: according to him the stages might be difficult to discern from each other as they flow rapidly from one to the other, or in some cases the flow takes place in such a manner that it cannot be said when one stage ends and another begins. Concerning violence, Brinton adds that it will occur or will be condoned because some in society, in times of revolution, profess ultimate knowledge about right and wrong, and this has the inevitable concomitant that there is a sense of righteousness and the assumption of the right to determine what is right and wrong, and the wrong (so-called evil) must and will be purged. This description is markedly similar to the eleventh element discussed in section 3, where the act of revolution conveys the force of legitimate justice on the revolutionary.

The most important element of critique that can be levelled against the analysis of Brinton is that he only analysed "Great Revolutions" such as the French (1789-1799) and the Russian revolutions (1917) that he viewed from an historical perspective. These revolutions are complete (see Huntington below) revolutions that do not reflect modern complexities in society or practical complexity such as nuclear or biologic weapons. The following scholar included for a more detailed analysis is Samuel Huntington.

\section{SP HUNTINGTON (FUNCTIONALISM)}

Functionalism is the school of thought that proposes to explain institutions and practices in terms of the functions they perform (Mclean \& McMillan 2003:214). Thus, according to Cohan (1975:120), functionalists concern themselves with a conflict potential in society that may or may not be realised (there are many ways in which developments can eventually play out). This is in direct opposition to the Marxist proposition that conflict is endemic and inevitable in society. According to Fukuyama (2006:xi), Huntington's work Political Order in Changing Societies (2006) had enormous influence, and as such has to be included in this perspective on revolution. The Functionalism school of thought can be disaggregated into the following components: degree of government, impact of 
modernisation, types of revolution, complete versus incomplete revolutions, and praetorian politics.

\subsection{Degree of government}

According to Huntington (2006:1), the most important distinction among countries concerns not their form of government, but their degree of government. The higher the levels of institutionalisation in a state, the better are the chances of that state's survival during times of internal upheaval. Institutionalisation or the legitimisation of the processes and structures of state organisations and power reflects the relationship between political institutions and the social forces (ethnic, religious, territorial, economic and/or status group) within the geographical boundaries of the state (Huntington 2006:8).

Modernisation (an attempt to gain a higher degree of government through capital investment), as happened in the Third World during the 1950 s and 1960s, produced political disorder.

If poor countries appear unstable, it is not because they are poor, but because they are trying to become rich. A purely traditional society would be ignorant, poor and stable. By the mid-twentieth century, however, all traditional societies were also transitional or modernizing societies. It is precisely the devolution of modernization throughout the world which increased the prevalence of violence about the world (Huntington 2006:41).

This instability is caused by a cascade of events set in motion by the effort to modernise.

\subsection{The impact of modernisation}

According to Huntington (2006:55), modernisation leads to the introduction of new ideas and values; this leads to social mobilisation. Because there is no concurrent economic development (refer to the J-curve of Davies) to satisfy demand, social frustration accumulates. People search for opportunities of socio-economic mobility, which also are limited. The people themselves have become (politically) mobilised (active) and want to improve their destiny; they are dissatisfied with the government and its institutions (which are also developing slowly) and this leads to un-channelled political participation. Unfortunately, no legal or legitimate structures (institutions) exist in which this up to now unknown level of participation can be dealt with in a positive manner. This leads to political instability. If such a situation is left uncontrolled, two types of revolutions (Western and Eastern) might result.

\subsection{Two types of revolution}

Huntington (2006:266-267) identifies two "patterns of revolution" - a Western and an Eastern revolution. According to the Western pattern, the political institutions of the old regime collapse as a first step, and then a mobilisation of various groups occurs with political benefits in view. The Eastern revolution, on the other hand, begins with the mobilisation of new groups and the building of parallel structures - the goal of which is the destruction of the current order:

In terms of our twin concerns of institutions and participation, the Western revolution moves through the collapse of the established political institutions, the expansion of participation, the creation of new institutions... the pattern of the Eastern revolution is quite different. The expansion of political participation and the creation of new political institutions are carried on simultaneously and gradually by the revolutionary counter elite and the collapse of the political institutions of the old regime marks the end rather than the beginning of the revolutionary struggle (Huntington 2006:271).

Both these two types of revolution involve the expansion of political participation, the organisation of that participation, and the destruction of the established order. Another distinction Huntington offers is between complete and incomplete revolutions.

\subsection{Complete versus incomplete revolutions}

According to Huntington (2006:335), the contribution of communism (especially Leninism) is the "complete revolution". This is a revolution where the chaos of dramatic social change is followed not by anarchy, but by the institutionalisation of new political structures. Incomplete revolutions, on the other hand, are explained as follows: "Before the Bolshevik revolution no revolution was politically complete," according to Huntington, "because no revolutionary leaders had formulated a theory explaining how to organise and to institutionalise the expansion of political participation which is the essence of revolution... Lenin solved this problem..." by enabling the formation of new government institutions during and sometimes before the revolution (Huntington 2006:335-337). Brinton calls this the illegal government. Part of the illegal government is rooted in praetorian politics.

\subsection{Praetorian politics}

Praetorianism, in a limited sense, refers to the intervention of the military in politics (Huntington 2006:195). In modernising societies, politics lacks autonomy, complexity, coherence and adaptability; all sorts of social forces become directly involved in general politics. Countries with political armies also have political clergies, political universities, political bureaucracies and political labour unions (Huntington 2006:195). The problem with a praetorian system is that confrontation of power occurs openly, without the mitigating concomitant effect of institutions such as the court systems, laws, and/or powerful government structures. Therefore, no agreement exists among the groups as to the legitimate methods for resolving conflict; this leads to military interference in politics that most commonly takes the form of a coup (Huntington 2006:196).

In summation: the following aspects regarding revolution are important according to Huntington: He presents the field of study of revolutions with a vast richness of concepts that fit into his broader perspective and theory on political decay. Brinton discusses the stages of revolution; Huntington pays attention 
to the causes with the issue of legitimacy of institutions during times of what he calls modernisation, central to his argument. Again, nothing in Huntington's Political Order in Changing Societies contradicts the elements set for in section3. Being a functionalist, Huntington focuses on what revolutions want ${ }^{3}$ to accomplish; therefore many of the changes in values, myths, systems and society as a whole that Huntington emphasises are included in the elements as described in section ${ }^{3}$.

The most important element of critique that can be levelled against Huntington is twofold in nature: 1) He sees modernisation as the primary cause of instability while there are several other important causes such as relative deprivation; and 2) He sees the modernisation process and the desire of poor Nations to become modern as inevitable. Furthermore Huntington as an example of the broader school, exemplifies the fact that conflict does not have a negative impact; it only has "functionalities", leading to some labelling the Functionalist School as practitioners of "consensus theory" (Holmwood 2005:100). The next scholar set up for analysis, Herbert Marcuse, comes from the modern Marxist tradition and as such differs considerably from the previous two.

\section{HERBERT MARCUSE (NEO-MARXIST)}

More recent theorists are classified as falling in the Marxist tradition because of their acceptance of the Marxist model of revolution and they are theorists and philosophers such as Herbert Marcuse, Franz Fanon and Régis Debray (Cohan 1975:110-111). Each made a major contribution to revolutionary analysis generally, and to modern Marxist analysis in particular. As an example of contemporary Marxist thought about revolution, the work of Marcuse will be examined with regard to the role of class, the Cultural Revolution, freedom, the role of the state, and what has been termed Marcuse's dilemma.

\subsection{The role of class}

In Marcuse's work on the role of class in revolution, he rejects the working class as a group with revolutionary potential. Marcuse states that society in the 1960 s and 70 s has become so rich that even the workers are well off and no longer have revolutionary potential. Thus, according to Marcuse, mobilisation of the population in the advanced industrial societies has tended to militate against the type of conflict that Marx foresaw. There has been a unification of former opposite classes that bears on the possibilities of social change. The revolutionary classes now are the outsiders, the exploited, the persecuted by other races, the unemployed and the unemployable (Cohan 1975:111; Woddis 1972:294). The revolution of this new revolutionary class will be a revolution encompassing all aspects of human existence and culture.

\subsection{The Cultural Revolution}

Marcuse also focuses on the totality of modern radicalism; what he calls "subversion of the not only established economic

The personalisation of a phenomenon such as revolution is a characteristic of the Functionalist School. and political structure", but also (and primarily) on the entire established culture which the radicals define as the "bourgeois culture" (Marcuse, 2001:123). It may, according to Marcuse, be that this all-encompassing Cultural Revolution not only precedes the political revolution, but at a certain stage absorbs the more traditional revolution. Under modern capitalism, basic economic institutions and relationships reproduce themselves in all spheres of society. This total integration has to meet its total negation through the total claim of the Cultural Revolution (Marcuse 2001:124). Yet, even this revolution cannot provide absolute "freedom".

\subsection{Freedom}

According to Marcuse, freedom exists only as a desired goal; there is no freedom in reality. That is the base from which all revolutions have to start as the continuum of history allows no break and every new society holds something from the previous. As Marcuse continues with this argument it becomes clear why stoic Marxists such as Woddis (1972) would criticise him. Firstly, Marcuse's arguments about new revolutionary classes and the new nature of the cultural revolution are difficult to understand, and secondly, he debunks the religious nature of Marxism even as he upholds the theoretical and practical value: "It must be emphasised that the Marxian base is... a human base", and thus has no scientific or religious value (Marcuse 2001:125). Therefore, the new revolutionary class must realise that even the "socialist-" or "Marxist-state" is fallible and in Marcuse's era has become entities driven by capital, and employing (and exploiting) workers.

\subsection{The role of the state}

According to Marcuse (1998:222), the societal tendency towards state socialism is anti-revolutionary:

Power over the means of production has been transferred to the state, which exercises this power through the employment of wage labour. The state has also assumed the role of the direction of capital as a whole. The direct producers do not control production (and with it their destiny) any more than they do the system of liberal-democratic capitalism. They remain subordinated to the means of production.

In this way, state socialism maintains the foundations of a class society. The implication of this is far-reaching - a socialist state organised in this way (direction of capital as a whole) is no longer the solution, but the object of revolution. This gives rise to a difference between Marcuse's interpretation of Marx and more traditional Marxists.

\subsection{Different interpretation of Marx}

Because Marcuse lived in different times from the original Marxist theorists, he evolved with the theories of Marxism: "Intellectual opposition to the prevailing form of life [in the 1960s and '70s] seems to become increasingly impotent and ineffective. The aim of this opposition: man's liberation from domination and exploitation has failed to materialise although the historical conditions for its realisation 
have been attained..." (Marcuse 1998:201).

In summation: the following aspects regarding revolution are important according to Marcuse: Because he lived in different times from the original Marxist theorists, he evolved together with the evolving theories of Marxism. In the first instance, Marcuse saw revolution occurring without violence, in the sphere of the mind. This process might then, as a second instance, later lead to violence and the Cultural Revolution evolving into a traditional revolution. This evolution is necessary to negate the effects of modern society where classes are structured differently. Therefore, the first bastion of revolution is the mind where a Cultural Revolution, encompassing every aspect of society, must with a compelling force occur. The new revolutionary class is the outsider in society, the unemployed and the unemployable, the people who are discriminated against and are left without recourse to the system. This outsider class will unite and so, comprising intellectuals and peasants, the spear of the revolution will be formed. In the case of Marcuse, there is a definite de-emphasis on violence as the Cultural Revolution will not necessarily need to include violence.

Criticism levelled at Marcuse includes the fact that he moved too far away from Marxist tenets in having discarded the dialectic and that elements of idealism can certainly been seen in his work. He also does not see "the workers" as the revolutionary class. Marcuse's conception of revolution without violence (at least in the first stages of the modern revolution) is in direct contrast to most definitions of revolution. Huntington, Brinton and especially, Marxists ${ }^{4}$ such as Lenin distinctly emphasises that revolutions incorporate violence. In Egypt and Tunisia during the Arab Spring ${ }^{5}$ revolutions started peacefully but quickly became violent as religious groups became to organise and religious intolerance became a sub theme.

\section{CONCLUSION}

It is possible to add various elements from the three scholars analysed above to the elements compiled in section 3. It would equally be possible to add elements from other scholars. This practice would then lead to a listing of elements some of which would overlap, with a resulting list maybe comprising several pages. This would be due to the nature of the use and perhaps overuse of the concept revolution, which was spoken of in the introduction. This practice would be the opposite of a characterisation which according to Babbie and Mouton (2008:113) should be 1) systematic, 2) mutually exclusive, and 3) exhaustive. For the purposes of this article the eleven elements in section 3 are proposed to fulfil the criteria above. Importantly, this assertion must be tested by the use of this characterisation (comprising the eleven elements) as a tool to analyse recent revolutions in order to ascertain the veracity and validity of the characterisation. Due to the limitations of space

\footnotetext{
$4 \quad$ Marx himself, in his early writings did not emphasize the need for
} violence in a revolution, later on in his life he became more "radical." this will be done in a follow-up article. Furthermore, in the work of each of the scholars analysed above, especially Brinton and Marcuse, the almost religious justification inherent in revolution is highlighted. In the text above the examples of China and South Africa were cited. It seems that the fever of revolution (according to Brinton) is brought to even higher temperature when the revolution is seen as a motive force in history (the Marxists) and so the revolution becomes a goal in itself, abstracted from other realities through ideology, in fact superseding other interpretations of reality (Brinton), just as a religion would be. This same revolution/religion also provides the opportunity to gain material and immaterial goods.

The characterisation above represents, in a deconstructionist sense, a new look at the concept revolution. After more than 100 years of what Sartori (1970:19) calls 'conceptual stretching', this might be exactly what is needed. Change and violence continue to characterise systems - be it on inter- or intrastate level. The demise of the 'predictability' of the 'stable bipolar world order' and the dominance of a few super-states has led to an escalation in lower level intrastate conflict. Conceptual clarity, as well as insightful analytical instruments, is needed to foster the understanding of these complexities. The characterisation of revolution in the first instance argues for the critical evaluation of the available literature, and secondly, endeavours to contribute to the hermeneutical process regarding the highly discursive concept of revolution. 


\section{BIBLIOGRAPHY}

Arslanian, V.A., 2013, 'Beyond revolution: Ending lawlessness impunity during revolutionary periods', Boston College International and Comparative Law Review 36(1):121-152.

Babbie, E. \& Mouton, J., 2008, The practice of social research, South African edition. Oxford University Press, Cape Town.

Brinton, C., 1965, The Anatomy of Revolution, Revised and expanded version, Prentice Hall, New York

Capriles, R., 2012, Leadership by Resentment: From Resentment to Redemption, Edward Elgar, Cheltenham, UK.

Cohan, A.S., 1975, Theories of revolution: an introduction. Thomas Nelson \& Sons, London.

Davies, J.C., 1962, 'Towards a Theory of Revolution', American Sociological Review 27(1) 5-19.

Fukuyama, F., 2006, In Huntington, S.P. Political order in changing societies (Foreword), Yale University Press, London.

Greene, T.H., 1990, Comparative revolutionary movements: search for theory and justice, 3rd ed. Prentice Hall, Englewood Cliffs, N.J.

Hirst, A., 2014, 'Derrida and political resistance: the radical potential of deconstruction' Globalisation, 12 (1):6-24.

Huntington, S.P., 2006, Political order in changing societies, Yale University Press, London.

Koselleck, R in Marinelli, M., 2014, 'China today: long live the revolution or a change in entropy', Postcolonial Studies. 17 (1):7-22.

Marcuse, H., 1998, Technology, war and fascism, Routledge, London.

Marcuse, H., 2001, Towards a critical theory of society, Routledge, London.

Marek, F., 1969, Philosophy of world revolution, Lawrence \& Wishart, London.

Marinelli, M., 2014, 'China today: long live the revolution or a change in entropy', Postcolonial Studies. 17 (1):7-22.

Marsh, D. \& Stoker, G., 2010, Theory and methods in political science, 3rd ed. St. Martins, New York.

Marx, K., 1992, The Communist Manifesto, Oxford University Press, New York.

McLean, I. \& McMillan, A. eds., 2003, Oxford Concise Dictionary of Politics, 2nd ed., Oxford University Press, Oxford.

Mouton, J. \& Marais, H.C., 1994, Basic concepts in the methodology of the social sciences, HSRC, Pretoria.

Nzimande, B., 2006, What is the National Democratic Revolution? http://www. sacp.org.za/main.php?ID=1850 SACP website (Accessed 11 March 2012, 3 July 2012).

Pettee, E.S., 1938, The process of revolution, Harper, New York.

Rossetti, J. 1992, 'Deconstruction, rhetoric and economics', Post-Popperian Methodology of Economics; Recent Economic thought, 27:211-234.

Sartori, G., 1970, 'Concept misformation in comparative politics', The American Political Science Review, 64(4):1033-1053.

Schram, S.R., 1972, 'Mao Tse-tung and the theory of the permanent revolution, 1958-69', The China Quarterly, 45 April-June 221-244.

Turok, B. ed., 2012, Readings in the ANC traditions. Volume II: History and ideolo- gy, Jacana, Auckland Park, South Africa.

Woddis, J., 1972, New theories of revolution: a commentary on the views of Frantz Fanon, Regis Debray \& Herbert Marcuse, International Publishers, New York.

Xiaobo, L in Marinelli, M., 2014, 'China today: long live the revolution or a change in entropy', Postcolonial Studies, 17 (1):7-22.

Zedong, M., 2009a, Collected writings of Chairman Mao, Volume 2: Guerrilla warfare, El Paso Norte, El Paso TX.

Zedong, M., 2009b, Collected writings of Chairman Mao, Volume 1: Politics and tactics, El Paso Norte, El Paso TX.

Zedong, M., 2009c, Collected writings of Chairman Mao, Volume 3: On policy, practice and contradiction, El Paso Norte, El Paso TX. 